\author{
Praca poglądowa/Review paper
}

\title{
Patogeneza skutków ubocznych radioterapii w tkankach prawidłowych
}

\section{Pathogenesis of side effects of radiation therapy in normal tissues}

Karolina Rzewuska ${ }^{1}$

${ }^{1}$ Uniwersytet Medyczny $w$ Poznaniu

\section{Streszczenie}

Kluczowym wyzwaniem w radioterapii jest dobranie odpowiednich maksymalnych dawek promieniowania docierających do komórek nowotworowych przy jednoczesnej minimalizacji uszkodzeń zdrowej tkanki. Powodzenie radioterapii w zwalczaniu guza zależy głównie od całkowitej dawki podanej w trakcie leczenia, zaś tolerancja na promieniowanie tkanek prawidłowych stanowi pewne ograniczenie w doborze maksymalnych dawek. W celu uniknięcia niepożądanych skutków po radioterapii pewnych progów dawek nie powinno się przekraczać. Ryzyko uszkodzenia popromiennego tkanek prawidłowych zwiększa się wraz z dawką całkowitą, liczbą frakcji radioterapii oraz objętością tkanek, które zostały napromienione. Szczególnie podatnymi na powikłania są pacjenci poniżej 10 roku życia oraz pacjenci powyżej 70 roku życia.

Wykorzystywane promieniowanie jonizujące w radioterapii powoduje uszkadzanie struktur komórkowych, odpowiedzialnych za podstawowe procesy komórkowe. Promienie X zderzają się z elektronami powodując jonizację cząsteczek. Elektrony te tracą zdolność do prawidłowego funkcjonowania w obrębie komórki. W przebiegu tego procesu uszkodzony zostaje kwas deoksyrybonukleinowy (DNA- z ang.deoxyribonucleic acid) co może powodować mutacje. Najbardziej podatnymi na popromienne uszkodzenia są komórki krwiotwórcze, komórki śródbłonka, śluzówek i przewodu pokarmowego. Można więc wyróżnić kilka efektów po kontakcie żywej komórki z promieniowaniem jonizującym. Pierwszym z nich może być tak duże uszkodzenie komórki, że nie będzie ona w stanie pełnić swoich funkcji i dojdzie do jej śmierci. Komórka może też stracić swoją zdolność do „reprodukcji” mimo, iż pozostaje żywa. Kod DNA może zostać uszkodzony na tyle, że powstające kopie komórek będą się znacznie różnić od komórki pierwotnej. Promieniowanie może też nie wywołać skutków ubocznych i nie mieć wpływu na komórkę.

Adres do korespondencji

Karolina Rzewuska

Uniwersytet Medyczny w Poznaniu

e-mail:k.kiryluk@vp.pl 


\begin{abstract}
The key challenge in radiotherapy is to select the appropriate maximum doses of radiation reaching the cancer cells while minimizing the damage to healthy tissue. The success of radiotherapy in the treatment of tumor depends mainly on the total dose administered during treatment whereas the tolerance to radiation of normal tissues is a certain limitation in the selection of maximum doses. In order to avoid any adverse effects after radiotherapy, certain dose thresholds should not be exceeded. The risk of radiation damage to normal tissues increases with the total dose, the number of radiotherapy fractions and the volume of tissues that have been irradiated. Patients under 10 years of age and patients over 70 are particularly susceptible to complications.

Radiation used in radiotherapy causes damage to cellular structures responsible for basic cellular processes. X-rays collide with electrons causing ionization of molecules. These electrons lose the ability to function properly within the cell. In the course of this process, deoxyribonucleic acid (DNA - deoxyribonucleic acid) is damaged, which can cause mutations. The most susceptible to radiation damage are hematopoietic cells, endothelial cells, mucous membranes and the gastrointestinal tract. Thus, several effects can be distinguished following the contact of a living cell with ionizing radiation. The first of them can be such a big damage to the cell that it may be able to perform its functions and may be killed. The cell may also lose its ability to reproduce, although it may remain alive. The DNA code might be damaged so much that the resulting cell copies would be significantly different from the original cell. Radiation may also not cause side effects or maid have not effect on the cell at all.
\end{abstract}

Słowa kluczowe: radioterapia, DNA, wolne rodniki, promieniowrażliwość, wczesne skutki uboczne promieniowania, późne skutki uboczne promieniowania,RIBE

Keywords: radiotherapy, DNA, free radicals, radiosesitivity, early side effects of radiation, late side effects of radiation, radiation induced bystander effect, $R I B E$

\title{
Wstęp
}

Wpływ promieniowania na żywą tkankę ma bardzo skomplikowany charakter i zależy od wielu czynników. Reakcja organizmu po ekspozycji na promieniowanie jest uwarunkowana przenikalnością promieniowania oraz względną skutecznością biologiczną. Kolejne istotne parametry to: moc dawki, rodzaj ekspozycji (jednorazowa czy frakcjonowana) oraz właściwości związane bezpośrednio z napromienionym obiektem tj. obszar ciała poddany ekspozycji, rodzaj napromienianych tkanek, wiek i płeć pacjenta, temperatura, równowaga hormonalna organizmu, nawodnienie i utlenienie napromienionego materiału biologicznego. Wrażliwość komórek na promieniowanie zwiększa się wraz ze wzrostem aktywności proliferacyjnej i zmniejsza się wraz ze wzrostem zróżnicowania tkanki.

Energia promieniowania, która zostaje pochłonięta przez tkankę powoduje jonizację ośrodka i przejście cząsteczek w stan wzbudzony. Jest to proces prowadzący do wielu przemian i szeregu różnych efektów biologicznych. Oddziaływanie promieniowania jonizującego na organizm żywy można podzielić na kilka następujących po sobie faz. Są to oddziaływania fizyczne, gdzie następuje jonizacja atomów i cząsteczek oraz powstawanie cząstek wtórnych $\left(10^{-16} \mathrm{~s}\right)$. Podczas oddziaływań fizyko-chemicznych może dojść do wtórnych reakcji produktów jonizacji, powstawania stabilnych cząsteczek i niestabilnych wolnych rodników (10 $\left.{ }^{-13} \mathrm{~s}\right)$. Odcinki DNA będące w fazie replikacji (podczas mitozy w fazie S, G2 lub M) są wyjątkowo wrażliwe na rodniki tlenowe oraz rodniki wodorotlenowe. W fazie odpowiedzi biologicznej mogą zostać zainicjowane procesy naprawcze, utrwalenie uszkodzeń lub śmierć komórki. W fazie efektów medycznych następuje promowanie i utrwalanie zmian.

Materiał genetyczny DNA jest najbardziej wrażliwą na promieniowanie częścią komórki żywej. Uszkodzenie makrocząsteczek, zachodzące pod wpływem promieniowania pozwala na ich ponowne odtworzenie dzięki informacji zawartej w DNA. Uszkodzenie białek zachodzi na skutek napromienienia dawkami wielokrotnie 
wyższymi od tych, które uszkadzają DNA. Proces degradacji białek spowodowany jest zniszczeniem ich struktury przestrzennej oraz wytworzeniem wiązań krzyżowych i rozerwaniem wiązań kowalencyjnych w łańcuchach peptydowych. Energia promieniowania docierająca do DNA prowadzi do oderwania at. wodoru od nici kwasu. Uszkodzenie zasady azotowej lub cukrowego szkieletu, może prowadzić do ich całkowitej utraty. W przypadku pęknięcia jednej nici kwasu systemy naprawcze w szybki sposób są w stanie naprawić uszkodzenia. Dwuniciowe pęknięcia powodują całkowite uszkodzenie łańcucha DNA. Podczas procesów naprawczych uwalniane są enzymy, które ułatwiają prawidłową odbudowę struktur w przypadku samoistnych uszkodzeń lub uszkodzeń spowodowanych wolnymi rodnikami. Naprawa może zajść bezproblemowo lub doprowadzić do mutacji przez wstawienie w miejsce uszkodzenia nieprawidłowego nukleotydu. Można wyróżnić mutacje somatyczne oraz genetyczne. Do zmian somatycznych, które zachodzą wcześniej zalicza się na przykład zaćmę oraz rumień skóry. Zmiany genetyczne na skutek mutacji genów i chromosomów zachodzą później i są one dziedziczone.

\section{Skutki uboczne napromieniowania tkanek}

Stopień uszkodzenia tkanek w skutek napromieniowania zależy od wielu czynników, między innymi od rodzaju tkanki i jej budowy jak i wielkości zastosowanych dawek. Każda tkanka posiada inną wrażliwość na promieniowanie jonizujące, jedne są mniej wrażliwe a drugie bardziej wrażliwe i szybciej ulegają uszkodzeniom. Stopień promienioczułości jest tym większy im mniejsze jest zróżnicowanie danej tkanki i większe zdolności do podziałów komórek. Różnice w promieniowrażliwości określa współczynnik wagowy tkanki , który jest przydatny w określeniu możliwości wystąpienia skutków stochastycznych oraz obliczaniu dawek skutecznych.

Tkanki, które mają szybką kinetykę odnawiania są bardziej wrażliwe na promieniowanie od tkanek, w których komórki proliferują rzadziej. Najbardziej wrażliwe na promieniowanie są gonady męskie i żeńskie. Podczas napromieniania okolic jąder dawka około 0,15 Gy powoduje nietrwałą bezpłodność u mężczyzn, a trwałą bezpłodność dawka od 3,5 do 6 Gy. Napromienianie okolic oczu przy otrzymaniu jednorazowej dawki od 2 do 10 Gy w krótkim czasie może powodować zmętnienie soczewki lub trwałe uszkodzenie wzroku. Napromienienie szpiku kostnego dawką powyżej 0,5 Gy upośledza jego funkcję krwiotwórczą. Powierzchnia skóry oraz kości jak również przełyk, tarczyca, wątroba, i pęcherz moczowy cechują się stosunkowo dużą odpornością na promieniowanie. W sytuacji narażenia na promieniowanie całego ciała dawkami, gdzie w narządach wewnętrznych dawki przekraczają 2 Gy, w ciągu kilku godzin w skutek uszkodzenia układu trawiennego mogą wystąpić mdłości. U pacjentów naświetlanych profilaktycznie przy ostrej białaczce limfatycznej lub grzybicy skóry głowy mogą wystąpić bóle głowy i senność- objawy te występują po kilku tygodniach od napromienienia i zazwyczaj ustępują samoistnie. Po ekspozycji na promieniowanie okolic ucha środkowego może dojść do uszkodzenia struktur znajdujących się w tylnej jamie czaszki z dyzartrią , ataksją, oczopląsem. Naświetlanie tylnej jamy czaszki oraz pnia mózgu w wyniku obrzęku i zamknięcia trąbki Eustachiusza może doprowadzić do zapalenia ucha środkowego i zapalenia gardła. Ekspozycje na duże dawki promieniowania skutkują oparzeniami popromiennymi. Pojawiają się one stopniowo i dają inny obraz kliniczny od poparzeń termicznych.

Do najczęściej występujących skutków ubocznych spowodowanych radioterapią należy osłabienie ogólne i spadek aktywności, zmiany we krwi spowodowane przez spadek liczby białych krwinek i płytek krwi, brak łaknienia, odczyny śluzówkowe w jamie ustnej, gardle, krtani i jamach nosowych, reakcje ze strony dróg oddechowych i serca, ze strony jelit i pęcherza moczowego, utrata włosów, odczyny skórne, odczyny ze strony odbytnicy, pochwy, sromu.

Skutki napromienienia mogą zostać ograniczone właściwą opieką medyczną. Pomocne może okazać się podawanie cytokin, transfuzje krwi lub przeszczep szpiku kostnego. Od kilkudziesięciu lat są prowadzone badania nad tzw. radioprotektorami. Badania nad radiobiologią i patologią molekularną dowodzą, że promieniowanie wywołuje skoordynowaną odpowiedź biologiczną na poziomie komórek i tkanek wywołaną wczesną aktywacją kaskad cytokin. Postępy w dziedzinie patologii molekularnej i radiobiologii tkanek 
prawidłowych poprawiły rozumienie efektów późnych normalnej tkanki i przesunęły punkt ciężkości z indukcji początkowego uszkodzenia na rozpoznawanie uszkodzeń i przebudowę tkanek.

\section{Wczesne skutki uboczne}

Budowa komórki jest bardzo złożona a jej prawidłowe funkcjonowanie zapewnia prawidłowy przebieg procesów komórkowych. Komórki tworzą tkanki oraz złożone układy biologiczne. Promieniowanie jonizujące w pierwszej kolejności uszkadza podstawowe elementy komórki, przez co jej elementy tracą zdolność do prowadzenia prawidłowych procesów w jej obrębie. Komórki śluzówek, krwi czy przewodu pokarmowego są jednymi z najbardziej podatnych komórek na uszkodzenia ze względu na to, że szybko się odnawiają. Komórki śluzówek żyją około dwóch tygodni, po tym okresie istnieje więc duże prawdopodobieństwo jej uszkodzenia w postaci zaczerwienienia lub owrzodzenia. Część komórek, które będą w stanie przetrwać ekspozycję promieni X zainicjuje w ciągu kilkunastu dni i doprowadzi do odnowienia tkanki śluzowej. Erytrocyty znajdujące się we krwi mają czas przeżycia około czterech tygodni, więc zaczynając napromienianie organizmu trzeba liczyć się z ujawnieniem wczesnych powikłań takich jak niedokrwistość. Promieniowanie zatrzyma proces tworzenia nowych erytrocytów, a funkcje będą pełniły dojrzałe komórki, które jeszcze żyją. Promieniowanie jonizujące szybko niszczy naczynia, co histologicznie objawia się naciekiem limfocytowym oraz proliferacją śródbłonka co może prowadzić do obrzęków naczyniopochodnych. Po napromieniowaniu dużymi dawkami ilość limfocytów w organizmie może drastycznie spadać, prowadząc do różnych skutków. Obserwuję się też zwyrodnienie włóknikowate, upośledzenie drożności cieniutkich włókien włośniczek oraz zakrzepice średnich i małych tętnic. Podczas napromieniania okolic głowy może dojść do pobudzenia systemu immunologicznego, gdyż glej uwalnia antygeny indukujące odpowiedzi autoimmunologiczne mające skutki w obrębie całego organizmu.

Wczesne skutki uboczne zazwyczaj nie prowadzą do poważnych konsekwencji w organizmie.

\section{Późne skutki uboczne}

Późne skutki uboczne dotyczą głównie tkanek, które proliferują wolno. Skutki te ujawniają się po kilku miesiącach lub nawet latach od napromieniania organizmu. Późne skutki uboczne dotyczą najczęściej zwyrodnień w obrębie mózgu, serca oraz płuc a także gruczołów wydzielniczych, gruczołów ślinowych, tętnic i zapaleń skóry. Zwyrodnienia najczęściej prowadzą do rozległych zwłóknień, infekcji oraz przewlekłych owrzodzeń czy nawet martwicy tkanek. Płuca, rdzeń kręgowy i narządy rozrodcze to narządy najbardziej wrażliwe na przekroczenie dawki tolerancyjnej. Po kilkunastu tygodniach od napromienienia okolic głowy można zaobserwować rozwijającą się leukoencefalopatię prowadzącą do senności i bólu głowy. Po około trzech do sześciu miesięcy po radioterapii okolic, w których znajdują się sploty nerwowe pojawiają się objawy uszkodzenia nerwów obwodowych, prowadząc do bólu, parestezji oraz niedowładów. Po upływie czterech lat można również zaobserwować obrzmienia i zwłóknienia okolic splotów nerwowych. Promieniowanie uszkadza w znacznym stopniu wzrok zmniejszając ostrość obrazu lub prowadząc do ograniczenia pola widzenia w ciągu około trzech lat. W przypadku dzieci, narażonych na duże dawki promieniowania, upośledzenie gruczołów dokrewnych zatrzymuje wzrost dziecka. Niedobór gonadotropin prowadzi zazwyczaj do opóźnienia procesu dojrzewania płciowego. U dorosłych zaś ekspozycja na promieniowanie jonizujące może skutkować trwałą niepłodnością. Ponadto do typowych późnych powikłań promieniowania zalicza się ryzyko pojawienia się wtórnego nowotworu- zazwyczaj białaczek, ale też chłoniaków i nowotworów litych. Wtórne nowotwory pojawiają się najczęściej między siódmym a dziesiątym rokiem po zakończeniu leczenia radioterapią.

W celu ograniczenia ryzyka wystąpienia wyżej wymienionych późnych skutków ubocznych dąży się do podawania w miarę najniższych możliwych dawek promieniowania i ich odpowiedniego frakcjonowania, by nie doprowadzić do zagrożenia życia pacjenta oraz nie spowodować jego kalectwa.

\section{Toksyczność radioterapii}

Ostre skutki występują podczas lub krótko po zakończeniu leczenia i są zwykle odwracalne i nie są ogólnie 
uważane za ograniczające dawkę. Wczesne reakcje wydają się być stosunkowo niewrażliwe na zmiany dawki promieniowania na frakcję, ale są wrażliwe na czas, w którym promieniowanie jest dostarczane. Przedłużone leczenie zmniejsza ostrą toksyczność, ale może zagrozić kontroli nowotworu. Późne efekty manifestują się od 6 miesięcy do kilku lat po radioterapii. Długi okres zapobiega dostosowywaniu dawki promieniowania do toksyczności u poszczególnych pacjentów, a związek między ostrymi i późnymi skutkami pozostaje niejasny. Ponieważ późne skutki uboczne mogą być trwałe, stanowią podstawę ograniczeń dawki dla toksyczności promieniowania. Późne efekty zazwyczaj występują w wolniej proliferujących tkankach, takich jak nerki, serce i centralny układ nerwowy. Patogeneza obejmuje zwłóknienie, zanik i uszkodzenie naczyń. Inne ważne późne, normalne skutki uboczne tkanek obejmują niedobory hormonów, niepłodność i tworzenie kolejnych nowotworów złośliwych. Późna toksyczność wydaje się być bardziej wrażliwa na zmiany dawki promieniowania na frakcję niż ostre reakcje tkanek i mniej wrażliwe na ogólny czas leczenia.

Wraz ze wzrostem całkowitej dawki promieniowania wzrasta prawdopodobieństwo rozwoju toksyczności. Relacje dawka-odpowiedź promieniowania dla normalnych tkanek mają próg przy niskich dawkach - które nie wywołują reakcji - i nasycają się przy wysokich dawkach. Niewielkie zmiany w dawce powodują stosunkowo duże różnice w toksyczności.

Różne typy komórek (zręby, naczynia krwionośne, miąższowe i odpornościowe) w napromieniowanej tkance oddziałują ze sobą i z układem odpornościowym przez cytokiny, aby wywołać reakcje zapalne i prozwłóknieniowe. Zmniejszenie liczby komórek, zapalenie, repopulacja i przebudowa przypominają proces gojenia ran i prowadzą do deterministycznych efektów. Mutacje wywołane promieniowaniem i niestabilność genomiczna prowadzą do efektów stochastycznych.

\section{Efekt sąsiedztwa}

Ciekawym zjawiskiem obserwowanym przez naukowców od 2011 roku w organizmie po napromienianiu, jest tak zwany efekt sąsiedztwa lub obserwatora ( $z$ ang. radiation induced bystander effect-RIBE). To zjawisko, w którym obserwuje się reakcję zdrowych komórek po napromieniowaniu innego obszaru. Reakcja zdrowych komórek wygląda jakby same były napromieniowane. Przez pewien czas twierdzono, że uszkodzenia struktur DNA i tkanek jest efektem bezpośredniej ekspozycji na promieniowanie tych struktur lub uszkodzeń powstających pośrednio w wyniku różnych procesów biochemicznych zachodzących w komórce po bezpośredniej ekspozycji. Zaobserwowano, że niektóre komórki zdrowych tkanek po ekspozycji organizmu na promieniowanie jonizujące wykazują zainicjowanie zmian biochemicznych, uszkodzenie DNA, zachodzą w nich mutacje, aberracje chromosomalne, dochodzi do niestabilności chromosomalnej, starzenia się komórki a nawet apoptozy. Zjawisko to zostało zbadane i dobrze udokumentowane, aczkolwiek mechanizm aktywowania tego zjawiska nie jest pełni znany. Naukowcy uważają, że w zależności od typu komórek zaangażowanych jest wiele różnych ścieżek prowadzących do wystąpienia RIBE.

Wykazano,żenawetpacjencinapromienianizogniskowanąwiązkąpodczas radioterapiisąnarażeninaskutki uboczne w zdrowych odległych tkankach znajdujących się w pewnej odległości poza polem napromieniania nowotworu. Komórki po napromieniowaniu umierają drogą apoptozy z uwolnieniem nukleosomów. Uwalniane nukleosomy, budujące chromatynę, integrując się ze zdrowymi komórkami, mogą wywoływać uszkodzenia kwasu deoksyrybonukleinowego prowadząc do stanów zapalnych. Ponadto nukleosomy krążące w krwioobiegu, mogą włączać się do genomów zdrowych komórek i powodować ogólnoustrojowe zaburzenia w organizmie. Wcześniej napromienione komórki wysyłają sygnały molekularne indukujące liczne zmiany w nienapromienionych okolicznych komórkach prowadząc do niepożądanych skutków w zdrowych komórkach i zdrowych tkankach. Mechanizm przenoszenia i międzykomórkowa komunikacja przez szczeliny jest głównym sposobem przesyłania sygnałów molekularnych. Najprawdopodobniej wspomniane mechanizmy mają wpływ na powstawanie i ostrość odczynów popromiennych oraz tworzeniu skutków ubocznych promieniowania w obrębie całego ciała lub w tkankach znajdujących się poza polem napromieniowania. Efekt obserwatora stwarza ryzyko niestabilności genetycznej i indukcji drugiego nowotworu. Działania niepożądane w tkankach prawidłowych są często spowodowane przez komórki nowotworowe, które 
pochłaniając pewną energię promieniowania inicjują różnicowanie komórek sąsiadujących lub bezpośrednio je uszkadzają. Uszkodzenia mogą się pojawić zarówno w niedużej odległości od pola napromienianego jak i w tkankach i narządach w bardzo dalekiej odległości. Najprawdopodobniej ma to związek z rodzajem tkanki. Wciąż zaś trwają badania sprawdzające, czy w efekcie wydzielania pewnych cząsteczek przez napromieniane komórki nowotworowe zostają uszkadzane tkanki zdrowe takie jak na przykład limfocyty czy komórki nabłonka i śródbłonka. Efekt ten jest istotny z punktu widzenia planowania leczenia przy wykorzystaniu najnowszych technik radioterapii takich jak radioterapia z modulowaną intensywnością dawki (IMRT) czy trójwymiarowa konformalna radioterapia (3D-CRT). Wynika to $\mathrm{z}$ faktu, iz podczas leczenia radioterapie te wykorzystują najnowsze techniki obniżające dawkę promieniowania w obszarze tkanek prawidłowych, natomiast mogłoby się okazać, że efekt sąsiedztwa jest w pewien sposób szkodliwy i potrafi doprowadzić do wzmożonych skutków ubocznych w tkankach prawidłowych.

\section{Mechanizm efektu sąsiedztwa}

W komórkach napromieniowanych, poza bezpośrednią jonizacją makrocząsteczek, działają uszkadzająco reaktywne formy tlenu, głównie hydroksylowy rodnik, $\mathrm{H}_{2} \mathrm{O} 2$ i rodnik ponadtlenkowy. Efektem ich działania są oksydacyjne uszkodzenia DNA. Czas półtrwania reaktywnej formy tlenu jest bardzo krótki, a odległość penetracji jest wyrażona w ułamkach mikrometra. Z tego względu czynniki te nie mogą dotrzeć do komórek nienapromienianych. Wykazano zaś, że po ekspozycji na promieniowanie mogą się pojawiać w komórce długo żyjące rodniki (wtórne) o okresie półtrwania około 20 godzin. Rodniki te pojawiając się w środowisku mogą być czynnikami indukującymi uszkodzenia DNA w komórkach, które nie zostały bezpośrednio napromienione. Wtórne wolne rodniki mają mniejszą zdolność uszkadzania informacji DNA niż rodniki, które powstały bezpośrednio w chwili napromienienia. Uszkodzenia informacji genetycznej wywołane przez rodniki wtórne mogą okazać się wystarczająco dużą przeszkodą do zatrzymania replikacji DNA i tym samym mogą doprowadzić do powielania uszkodzonego DNA w następnych generacjach komórek, aż w końcu do mutacji oraz transformacji nowotworowej.

\section{Podsumowanie}

Radioterapia skupia się ona na dobraniu odpowiednich maksymalnych dawek promieniowania docierających do komórek nowotworowych, przy jednoczesnej minimalizacji uszkodzeń zdrowej tkanki. Mimo to skutków ubocznych tkankach prawidłowych nie sposób uniknąć. Uszkodzenia popromienne zdrowych tkanek są klasyfikowane na uszkodzenia ostre, gdzie początki objawów pojawiają się w ciągu miesiąca po napromienianiu, wczesne opóźnione z początkiem objawów miedzy pierwszym a szóstym miesiącem oraz późne opóźnione, gdzie pierwsze objawy pojawiają się dopiero po upływie sześciu miesięcy od napromienienia. W przewidywaniu odwracalności uszkodzeń tkanek przydatne jest określanie czasu, w którym doszło do wystąpienia powikłań po ekspozycji organizmu na promieniowanie. W przypadku uszkodzeń ostrych i wczesnych można oczekiwać poprawy i ustąpienia objawów. Późne powikłania mają charakter postępujący i zazwyczaj nieodwracalny.

\section{Piśmiennictwo/References}

[1] E. Louis, S.A. Mayer, L.P. Rowland, red. wyd. pol. W. Turaj. Merritt Neurologia - tom 1-2; Wyd Edra Urban \& Partner. Rok 2017

[2] W. Lobodziec. Podstawy fizyki promieniowania jonizującego na użytek radioterapii i diagnostyki radiologicznej. Wydawnictwo Uniwersytetu Śląskiego. Rok 2016, ISBN: 9788379963881

[3] P.Jaracz. Promieniowanie jonizujące w środowisku człowieka. Fizyka. Skutki radiologiczne. Wydawnictwo Uniwersytetu Warszawskiego. Rok 2001, ISBN: 83-235-0146-7

[4] P.W. Lampert, R.L. Devis, Delayed effects of radiation on the human CNS-early and late delayed reactions.; Neurology, s. 912-917

[5] Stone, Anscher, Coleman, McBride. Effects of radiation on normal tissue: consequences and 
mechanisms. The Lancet Oncology. Rok 2003; s. 529-536.

[6] Bentzen, Constine, Deasy, Eisbruch, Jackson, Marks. Normal Tissue Effects in the Clinic (QUANTEC): an introduction to the scientific issues. Int J Radiat Oncol Biol Phys. Rok 2010

[7] S.M. Bentzen. Preventing or reducing late side effects of radiation therapy: radiobiology meets molecular pathology. Nat Rev Cancer. Rok 2006; s.702-713.

[8] J.S Haviland, M.Mannino, C.Griffin, N.Porta, M.Sydenham, J.M. Bliss, J. R. Yarnold. Late normal tissue effects in the arm and shoulder following lymphatic radiotherapy: Results from the UK START (Standardisation of Breast Radiotherapy) trials Radiother Oncol. Rok 2018 s.155-162.

[9] Borgmann, Roper , El-Awady , Brackrock, Bigalke, Dork, Alberti , Dikomey , Dahm-Daphi. Indicators of late normal tissue response after radiotherapy for head and neck cancer: fibroblasts, lymphocytes, genetics, DNA repair, and chromosome aberrations.; Radiother Oncol. Rok 2002; s.141-152.

[10] Sterpone, Cornetta, Padua, Mastellone, Giammarino, Testa, Tirindelli , Cozzi , Donato. DNA repair capacity and acute radiotherapy adverse effects in Italian breast cancer patients.; Mutat Res. Rok 2010; s. $43-48$.

[11] L.A. Jones,D. Scott, R.Cowan, S.A. Roberts. Abnormal radiosensitivity of lymphocytes from breast cancer patients with excessive normal tissue damage after radiotherapy: chromosome aberrations after low dose-rate irradiation.; Int J Radiat Biol. Rok 1995; s 519-528.

[12] G.C. Barnett, C. M. L. West, A.M. Dunning, R. M. Elliott, C.E. Coles, P.D. P. Pharoah, N.G. Burnet.; Normal tissue reactions to radiotherapy.; Nat Rev Cancer. Feb; 9(2). Rok 2009; s. 134-142

[13] S. Kirolikar, P. Prasannan, G.V. Raghuram, N.Pancholi, T.Saha, P.Tidke, P. Chaudhari, A. Shaikh, B.Rane, R.Pandey, H.Wani, N. K. Khare, S.Siddiqui, J. D’souza, R.Prasad, S. Shinde, S.Parab, N. K. Nair, K. Pal , I. Mittra. ;Prevention of radiation-induced bystander effects by agents that inactivate cell-free chromatin released from irradiated dying cells.; Cell Death \& Diseasevolume 9, Artykuł nr 1142. Rok 2018

[14] K.Ariyoshi, T.Miura, K. Kasai, Y.Fujishima, A.Nakata, M. Yoshida. Radiation-Induced Bystander Effect is Mediated by Mitochondrial DNA in Exosome-Like Vesicles.; Scientific Reports 9, Artykuł nr 9103. Rok 2019, s. 1-14 